\title{
MENINGKATKAN PERTUMBUHAN DAN HASIL PAKCOY (BRASSICA JUNCEARAPAL.) DENGAN MENGATUR DOSIS NUTRISI AB MIX AGRIFARM DAN UMUR BIBIT SECARA HIDROPONIK SISTEM NFT
}

\author{
I WAYAN SUKASANA ${ }^{1)}$, I NENGAH KARNATA ${ }^{2)}$, BUDI IRAWAN ${ }^{3)}$
}

\author{
PS. Agroteknologi, Fakultas Pertanian, Universitas Tabanan
}

e-mail: ${ }^{1)}$ wayansukasana@gmail.com ; ${ }^{2)}$ karnata.nengah@gmail.com; ${ }^{3)}$ irawanbudi404@gmail.com;

\section{ABSTRAK}

Pakcoy adalah jenis tanaman sawi yang cukup digemari oleh masyarakat, sangat cocok dibudidayakan mengingat kebutuhan masyarakat akan sayuran yang cukup besar. Kebutuhan masyarakat akan sayuran yang segar dan bebas pestisida menjadi pilihan saat ini sejalan dengan pemahaman masyarakat akan pola makanan yang sehat. Alternatif dalam pemenuhan tersebut dipilihlah penanaman dengan media hidroponik. Hidroponik merupakan alat pengganti media tanah yang dapat digunakan untuk menanam tanaman sayuran.Dengan adanya hidroponik diharapkan dapat mengatasi penyempitan lahan pertanian sertamengurangi penggunaan pestisida mengingat pestisida sangat berdampak pada kesehatan manusia serta lingkungan.

Penelitian ini bertujuan untuk mengetahui pengaruh dosis nutrisi $\mathrm{AB}$ mix agrifarm dan umur bibit serta intraksinya terhadap pertumbuhan dan hasil tanaman pakcoy, penelitian ini dilaksanakan di Kebun percobaan Fakultas Pertanian Universitas Tabanan yang dimulai pada tanggal 9 Desember 2018 sampai dengan tanggal 12 januari 2019.

Penelitian menggunakan Rancangan Acak Kelompok (RAK) yang terdiri dari dua faktor. Faktor pertama yaitu dosis nutrisi $\mathrm{AB}$ mix agrifarm $(\mathrm{N})$ yang terdiri atas tiga tingkat dosis yaitu dosis $850 \mathrm{ppm}$, $1050 \mathrm{ppm}$ dan $1250 \mathrm{ppm}$. Faktor kedua yaitu umur bibit (U) yang terdiri atas dua tingkat umur bibit yaitu umur bibit 1 minggu dan 2 minggu.Setiap perlakuan di ulang sebanyak empat kali.

Hasil penelitian mendapatkan interaksi perlakuan dosis agrifarm dengan umur bibit menunjukkan pengaruh yang sangat nyata $(\mathrm{p}<0,01)$ terhadap semua parameter kecuali terhadap parameter jumlah daun umur 35 hst yang menunjukkan pengaruh tidak nyata $(\mathrm{p} \geq 0,05)$. Berat basah ekonomis $\operatorname{tanaman}^{-1}$ dan BKO hasil ekonomis tanaman ${ }^{-1}$ tertinggi dihasilkan pada perlakuan kombinasi $\mathrm{N}_{3} \mathrm{U}_{2}$ yaitu sebesar masing-masing secara berurutan $244,09 \mathrm{~g}$ dan $78.10 \mathrm{~g}$ atau meningkat masing-masing $57,78 \%$ dan $293,85 \%$ dibandingkan dari hasil terendah yang dihasilkan oleh perlakuan kombinasi $\mathrm{N}_{1} \mathrm{U}_{1}$ yaitu sebesar $154,71 \mathrm{~g}$ dan $19,83 \mathrm{~g}$.

Kata kunci :nutrisi AB mix Agrifarm, umur bibit, Pakcoy(Brassica juncea rapa L.), Hidroponik NFT.

\section{ABSTRACT}

Pakcoy is a type of mustard plant that is quite popular with the community, it is very suitable to be cultivated considering the need for vegetables is quite large. The community's need for fresh and pesticidefree vegetables is a choice now in line with the community's understanding of a healthy diet. Alternatives to fulfillment are chosen by planting with hydroponic media. Hydroponics is a substitute for soil media that can be used to grow vegetable crops. The presence of hydroponics is expected to be able to overcome the narrowing of agricultural land and reduce the use of pesticides considering that pesticides greatly affect human health and the environment.

This study aims to determine the effect of nutritional doses of $A B$ mix agrifarm and age of seedlings and their interactions on the growth and yield of pakcoy plants, this study is carried out in the experimental garden of the Faculty of Agriculture, Tabanan University which began on 9 December 2018 until 12 January 2019.

The study used a Randomized Block Design (RBD) consisting of two factors. The first factor is the nutritional dose of $A B$ mix agrifarm $(N)$ which consists of three dose levels, namely the dose of $850 \mathrm{ppm}$, $1050 \mathrm{ppm}$ and $1250 \mathrm{ppm}$. The second factor is the age of seedlings $(U)$ which consists of two seedling age 
levels, namely the age of seedlings 1 week and 2 weeks. Each treatment is repeated four times. The results of the study obtained the interaction of dose agrifarm treatment with seed age showed a very significant effect ( $p 10.01$ ) on all parameters except for the parameters of the number of leaves aged 35 days old which showed no significant effect ( $p 50.05$ ). The economical wet weight of plant-1 and BKO of the highest yield of 1-crop yield is produced in the combination treatment of $N 3 U$, which amounted to respectively $244.09 \mathrm{~g}$ and $78.10 \mathrm{~g}$ or increased respectively by $57.78 \%$ and $293.85 \%$ compared to results the lowest produced by the combination treatment of N1U1 is $154.71 \mathrm{~g}$ and $19.83 \mathrm{~g}$.

Keywords: Agrifarm AB mix nutrition, seed age, Pakcoy (Brassica juncea rapa L.), NFT Hydroponics.

\section{PENDAHULUAN}

\section{Latar Belakang}

Perkembangan Ilmu dan teknologi dewasa ini berimbas pula pada teknologi dalam budidaya tanaman.Salah satunya adalah penerapan budidaya tanaman sayuran dengan sistem hidroponik. Sistem hidroponik mulai banyak diterapkan untuk menjawab masalah yang semakin sempitnya lahan pertaniandan juga sangat cocok diterapkan di daerah perkotaan dengan keterbatasan lahan yang ada.

Teknologi bertanam dengan sistem hidroponik dikembangkan karena semakin berkurangnya lahan produktif untuk perkembangan komoditaspertanian, terutama akibat perkembanganindustri dan jasa, sehingga usaha pertanian konvensional semakin tidak kompetitif karena semakin tingginya harga lahan (Suhardiyanto,2006).

Istilah hidroponik yang berasal dari bahasa latin yang berarti hidro (air) dan ponos (kerja). Istilah hidroponik pertama kali dikemukakan oleh W.F.Gericke dari University of California padaawal tahun 1930an, yang melakukan percobaan hara tanamandalamskalakomersial yang selanjutnya disebut nutrikultur atau hidroponik. Media hidroponik diberilarutan hara yang yang mengandung semuaelemen esensial yang diperlukan untuk pertumbuhan dan perkembangan normal tanaman (Susila,2009).

Tanaman sawi pakcoy (Brassica juncea L) merupakan salah satu jenis yang telah dibudidayakan oleh masyarakat karena memiliki komersial dan prospek yang baik.Pakcoysalah satu jenis tanamansayur- sayuran yang sangat digemari masyarakat baik masyarakat kelas bawah maupun masyarakat kelas atas (Haryanto,2001).

Budidaya pada tanaman pakcoy ini diperbanyak melalui benih dan memerlukan persemaian, pindah tanam sebaiknya dilakukan pada stadia tanam yang tepat. Pindah tanam lebih dini akan mempercepat adaptasi tanaman terhadap lingkungan, sehingga pertumbuhan tanaman tidak terhambat dan dapat menghasilkan bagian vegetatif yang lebih baik. Jika pindah tanam terlambat, maka tanaman tidak mempunyai cukup waktu untuk menyelesaikan pertumbuhan vegetatifnya, tanaman lebih cepat menua dan cepat memasuki stadia generatif (Vavrina,1998).

Waktu pindah tanam yang tepat ditentukan, selain oleh jenis tanaman dan kultivar juga ditentukan oleh kondisi lingkungan tempat tanam dipindah tanamkan, serta teknik budidaya (Vavrina,1998; Damanto et al.,1993).

Selain media tanam, formulasi hara merupakan hal yang sangat penting dalam budidaya secara hidroponik. Menurut Haryanto et al.(2002) larutan yang diberikan untuk tanaman hidroponik harus mengandung unsur hara makro dan mikro yang diberikan secara teratur serta efesien. Nutrisi hidroponik dapat diperoleh dengan meramu sendiri atau membelinya dalam bentuk siap pakai.Nutrisi hasil ramuan sendiri digunakan oleh orang yang menjadikan budidaya hidroponik sebagai suatuusaha.Sementara nutrisi dalam bentuk siap pakai biasanya lebih banyak digunakan karena formulasi yang dibuat telah teruji terlebih dahulu.

Saat ini banyak jenis nutrisi yang digunakan dalam budidaya tanaman secara hidroponik, salah satunya adalah nutrisi $\mathrm{AB}$ mix agrifarm. Larutan nutrisi $\mathrm{AB}$ mix agrifarmmerupakan larutan hara yang lengkap terdiri dari larutan hara stok Ayang berisi unsur hara makro dan stok B berisi larutan unsur hara mikro. Pemberian nutrisi $\mathrm{AB}$ mix agrifarm pada tanaman akan memenuhi unsur-unsur hara yang dibutuhkan oleh tanaman untuk dapat tumbuh dengan baik dan sehat. Untuk kebutuhan tersebut pemberian dosis yang tepat pada nutrisi $\mathrm{AB}$ mix agrifarm sangat perlu dilakukan pengujian pada berbagai jenis tanaman.

Berdasarkan permasalahan tersebut maka dilakukanlah penelitian ini untuk menguji tingkat dosis nutrisi $\mathrm{AB}$ mix agrifarm yang dibutuhkan dan umur bibit pada tanaman pakcoy.Tujuan penelitianadalah untuk mengetahuipertumbuhan dan hasil tanaman pakcoy (Brassica juncea rapaL.) yang tertinggi pada 
pemberian dosis agrifarm dan umur bibit. Hipotesa yang diajukan dalam penelitian ini yaitu Pemberian dosis nutrisi $\mathrm{AB}$ mix agrifarm $1050 \mathrm{ppm}$ dan umur bibit 2 minggu memberikan pertumbuhan dan hasil pada tanaman pakcoy (Brassica juncearapaL.) yang tertinggi.

\section{METODE PENELITIAN}

\section{Rancangan Penelitian}

Penelitian dilakukan dengan menggunakan Rancangan Acak Kelompok (RAK) pola faktorial dengan dua faktor perlakuan yang dicoba adalah dosis nutrisi $\mathrm{AB}$ mix agrifarm $(\mathrm{N})$ dan umur bibit tanaman pakcoy (U).Perlakuan dosis nutrisi $\mathrm{AB}$ mix agrifarm terdiri atas tiga tingkat dosis yaitu : $\mathrm{N}_{1}=850 \mathrm{ppm} ; \mathrm{N}_{2}=1050$ ppm $; \mathrm{N}_{3}=1250 \mathrm{ppm}$, sedangkan faktor kedua adalah umur bibit (U) yang terdiri dari dua tingkat yaitu:Umur bibit 1 minggu $\left(\mathrm{U}_{1}\right)$ dan umur bibit 2 minggu $\left(\mathrm{U}_{2}\right)$. Dengan demikian terdapat 6 kombinasi perlakuan yaitu antara pemberian dosis nutrisi $\mathrm{AB}$ mix agrifam $(\mathrm{N})$ dan umur bibit $(\mathrm{U})$ yang diulang sebanyak empat kali.

Penelitian ini dilakukan di kebun percobaan Fakultas Pertanian Universitas Tabanan yang berlangsung dari tanggal 9 Desember 2018 sampai dengan 12 Januari 2019. Bahan yang digunakan adalah benih sawi pakcoy (Brassica juncea rapa L), larutan Nutrisi AB mix agrifarm, Rockwool, Net pot. Alat yang digunakan yaitu rak hidroponik, gelas ukur, mistar, timbangan, TDS meter, $\mathrm{pH}$ meter dan alat- alat tulis.

\section{Pelaksanaan Penelitian}

Persemaian dilakukan pada rockwool yang telah disiapkan di dalam wadah persemaian dan kemudian biji pakcoy dimasukan ke dalam rockwool yang telah dilubangi. Media semai rockwool dipertahankan agar tetap basah, maka dilakukan pengontrolan setiap 3 hari sekali, bila media semai kurang air dapat dilakukan penyiraman agar bibit bisa tumbuh dengan optimal.Pada umur tiga hari benih sudah mulai tumbuh, kemudian diberi sinar matahari bertujuan untuk mempercepat pertumbuhan serta menguatkan tanaman hal ini dilakukan sampai penanaman. Dalam penyemaian ini dilakukan sesuai dengan perlakuan penelitian yaitu penyemaian yang pertama dilakukan untuk umur bibit dua minggu, setelah penyemaian pertama berumur satu minggu kemudian dilanjutkan penyemaian yang kedua yaitu utuk bibit umur satu minggu. Satu minggu kemudian kedua bibit tersebut ditanam secara bersamaan di dalam alat hidroponik yang telah disiapkan.

Setelah bibit berumur 2 minggu dan 1 minggu HST sesuai perlakuan maka bibit tersebut dipindahkan kedalam rak hidroponik sistem NFT yang sudah dipersiapkan.Pemberian nutrisi dilakukan dengan interval waktu yaitu 5 kali, yaitu pada awal penanaman, kemudian umur 7 HST, 14 HST, 21 HST, dan 28 HST. Dalam pemberian nutrisi ini dipertahankan atau tetap sesuai dengan masing-masing perlakuan hingga tanaman dipanen. Untuk mendapatkan dosis nutrisi sesuai dengan perlakuan diukur dengan TDS meter. Pemeliharaan meliputi pengecekan dosis nutrisi $\mathrm{AB}$ mix agrifarm yang dipertanhankan tetap sesuai dengan dosis perlakuan dengan mengukur konsentrasi air hidroponik dengan TDS meter. Pengontrolan air nutrisi pada tendon hidroponik, kalau sampai jauh berkurang maka ditambahkan dengan air supaya volumenya tetap dan penambahan nutrisi $\mathrm{AB}$ mix untuk mendapkan dosis nutrisi yang tetap sesuai dengan perlakuan. Pengontrolan hama dan penyakit dilakukan pengamatan secara visual. Pemanenan sawi pakcoy yaitu pada umur 35 HST, cara memanen tanaman pakcoy yaitu dengan mencabut seluruh bagian tanamannya.

\section{Pengamatan}

Pengamatan parameter yang diamati meliputi: Tinggi tanaman $(\mathrm{cm})$, Jumlah Daun (helai), Luas Daun $(\mathrm{cm})$, Berat basah bagian atas tanaman $(\mathrm{g})$, Berat basah bagian bawah tanaman $(\mathrm{g})$, Berat basah total tanaman (g), Berat basah ekonomis (g), Berat basah non ekonomis (g), Berat Kering Oven bagian atas tanaman (g), Berat Kering Oven bagian bawah tanaman (g), Berat Kering Oven Total Tanaman (g), Berat Kering Oven Ekonomis (g), Berat Kering Oven Non Ekonomis(g), Indeks panen\%.

Data dianalisis secara statistika dengan menggunakan analisis varian. Pengaruh interaksi yang nyata terhadap variabel yang diamati, maka untuk membandingkan nilai antar perlakuan kombinasi digunakan Uji Duncan pada taraf 5\%, sedangkan uji Beda Nyata Terkecil (BNT) taraf 5\% untuk membandingkan perlakuan tunggal apabila uji F menunjukkan interaksi yang tidak nyata(Gomez dan Gomez, 1995). 


\section{HASIL DAN PEMBAHASAN}

\section{Hasil Penelitian}

Hasil analisis statistika menunjukan bahwa interaksi antara perlakuan dosis nutrisi $\mathrm{AB}$ mix agrifarm dan umur bibit $(\mathrm{N} \times \mathrm{U})$ berpengaruh sangat nyata $(\mathrm{p}<0,01)$ terhadap seluruh parameter yang diamati, dan tinggi tanaman umur 35 hst menunjukkan pengaruhyang berbeda tidak nyata( $\mathrm{p} \geq 0,05)$ (Tabel 4.1).

Perlakuan tunggal dosis nutrisi $(\mathrm{N})$ memberikan pengaruh beda sangat nyata $(\mathrm{p}<0,01)$ terhadap semua parameter yang diamati, sedangkan parameter tinggi tanaman umur 35 hstdan berat basah bagian bawah $\operatorname{tanaman}^{-1}$ menunjukan pengaruh beda tidak nyata $(\mathrm{p} \geq 0,05)$ (Tabel 4.1). Perlakuan tunggal umur bibit (U) menunjukkan pengaruh yang berbeda sangat nyata $(\mathrm{p}<0,01)$ terhadap sebagian besar parameter yang diamati, kecuali terhadap luas daun tanaman ${ }^{-1}$ yang menunjukkan pengaruh berbeda tidak nyata $(p \geq 0,05)$ (Tabel 1).

Tabel 1. Signifikansi Pengaruh Nutrisi Agrifam (N) dan Umur Bibit (U) terhadap Parameter yang Diamati

\begin{tabular}{lllll}
\hline No & Parameter & \multicolumn{3}{c}{ Perlakuan } \\
\cline { 3 - 5 } & & $\mathrm{N}$ & $\mathrm{U}$ & $\mathrm{N}$ x U \\
\hline 1. & Tinggi tanaman $(\mathrm{cm}) 35 \mathrm{HST}$ & $\mathrm{ns}$ & $* *$ & $\mathrm{~ns}$ \\
2. & Jumlah daun (helai) 35 HST & $* *$ & $* *$ & $* *$ \\
3. & Luas Daun $\left(\mathrm{cm}^{2}\right)$ & $*$ & $\mathrm{~ns}$ & $* *$ \\
4. & Berat basah bagian atas tanaman $(\mathrm{g})$ & $* *$ & $* *$ & $* *$ \\
5. & Berat basah bagian bawah tanaman $(\mathrm{g})$ & $\mathrm{ns}$ & $* *$ & $* *$ \\
6. & Total berat basah $(\mathrm{g})$ & $* *$ & $* *$ & $* *$ \\
7. & Berat basah ekonomis $(\mathrm{g})$ & $* *$ & $* *$ & $* *$ \\
8. & Berat basah non ekonomis $(\mathrm{g})$ & $* *$ & $* *$ & $* *$ \\
9. & BKO tanaman bagian atas $(\mathrm{g})$ & $* *$ & $* *$ & $* *$ \\
10. & BKO tanaman bagian bawah $(\mathrm{g})$ & $* *$ & $* *$ & $* *$ \\
11. & BKO total tanaman $(\mathrm{g})$ & $* *$ & $* *$ & $* *$ \\
12. & BKO ekonomis $(\mathrm{g})$ & $* *$ & $* *$ & $* *$ \\
13. & BKO non ekonomis $(\mathrm{g})$ & $* *$ & $* *$ & $* *$ \\
14. & Indeks panen $(\%)$ & $* *$ & $* *$ & $* *$ \\
\hline
\end{tabular}

\footnotetext{
Keterangan : $\mathrm{ns}=$ berpengaruh tidak nyata $(\mathrm{p} \geq 0,05)$

$*$ = berpengaruh nyata $(\mathrm{p}<0,05)$

$* *$ berpengaruh sangat nyata $(\mathrm{p}<0,01)$

HST $=$ hari setelah tanam
}

\section{Tinggi Tanaman $(\mathrm{cm})$}

Hasil analisis statistika menunjukkan bahwa interaksi antara kedua perlakuan ( $\mathrm{N} \mathrm{x} \mathrm{U}$ ) umur 35 hst berpengaruh tidak nyata $(\mathrm{p} \geq 0,05)$ (Tabel 1$)$.

Tinggi tanaman pada umur 35 hst akibat pengaruh dosis nutrisi AB mix agrifarm menunjukkan pengaruh yang tidak nyata dengan tinggi rata-rata sebanyak $7,61 \mathrm{~cm}$. Sedangkan pengaruh umur bibit pada perlakuan umur bibit 2 minggu menunjukkan tinggi sebesar $8,13 \mathrm{~cm}$ yang nyata lebih tinggi $(\mathrm{p}<0,05)$ dibandingkan dengan umur bibit 1 minggu yaitu sebesar 7,09 $\mathrm{cm}$ (Tabel 2). 
Tabel 2. Rata - rata Tinggi Tanaman 35 HST Akibat Pengaruh Perlakuan Dosis Nutrisi (N) dan Umur Bibit (U).

\begin{tabular}{cc}
\hline Perlakuan & Tinggi tanaman $(\mathrm{cm})$ \\
\hline Dosis nutrisi (N); & $7.61 \mathrm{a}$ \\
$\mathrm{N}_{1}$ & $7.59 \mathrm{a}$ \\
$\mathrm{N}_{2}$ & $7.63 \mathrm{a}$ \\
$\mathrm{N}_{3}$ & $\mathrm{~ns}$ \\
\hline BNT 5\% & $7.09 \mathrm{~b}$ \\
\hline Umur bibit (U) : & $8.13 \mathrm{a}$ \\
$\mathrm{U}_{1}$ & \\
$\mathrm{U}_{2}$ & 0.09 \\
\hline BNT 5\%
\end{tabular}

Keterangan: Nilai rata-rata yang diikuti oleh huruf yang sama pada kolom yang sama menunjukkan perbedaan yang tidak nyata pada uji BNT dengan taraf $5 \%$

\section{Jumlah Daun Tanaman ${ }^{-1}$ (helai)}

Pada Tabel 3 menunjukkan jumlah daun tertinggi dicapai pada perlakuan kombinasi dosisNutrisi AB Mix agrifarm dengan umur bibit ( $\mathrm{N}$ x U) pada $\mathrm{N}_{2} \mathrm{U}_{1}$ yaitu sebesar 29,50 helai, meningkat sebesar 40,48\% dibandingkan dengan jumlah daun terendah yang dicapai oleh $\mathrm{N}_{1} \mathrm{U}_{1}$ yaitu 21,00 helai.

\section{Luas Daun $\operatorname{Tanaman}^{-1}\left(\mathrm{~cm}^{2}\right)$}

Parameter luas daun tertinggi diperoleh pada perlakuan kombinasi $\mathrm{N}_{3} \mathrm{U}_{1}$ yaitu $\left(88,25 \mathrm{~cm}^{2}\right)$, meningkat sebesar 52.89\% dibandingkan dengan hasil terendah pada perlakuan $\mathrm{N}_{1} \mathrm{U}_{1}\left(57.72 \mathrm{~cm}^{2}\right)$ (Tabel 3).

\section{Berat Basah Bagian Atas Tanaman ${ }^{-1}(\mathrm{~g})$}

Berat basah bagian atas tanaman ${ }^{-1}(\mathrm{~g})$ akibat pengaruh dosis nutrisi AB Mix agrifarm dengan umur bibit tertinggi pada perlakuan $\mathrm{N}_{3} \mathrm{U}_{2}$ yaitu 325,69g meningkat sebesar $64.79 \%$ dari berat basah bagian atas tanaman ${ }^{-}$ ${ }^{1}$ terendah pada perlakuan $\mathrm{N}_{1} \mathrm{U}_{1}$ yaitu 197.64g (Tabel 3).

Tabel 3. Pengaruh Kombinasi Dosis Nutrisi AB Mix Agrifarm (N) dan Umur Bibit (U) terhadap Jumlah ${\text { Daun } \operatorname{tanaman}^{-1} \text {, Luas daun tanaman }}^{-1}$ dan Berat basah bagian atas $\operatorname{tanaman}^{-1}(\mathrm{~g})$

\begin{tabular}{cccc}
\hline & \multicolumn{3}{c}{ Parameter } \\
\cline { 2 - 4 } Perlakuan & $\begin{array}{c}\text { Jumlah daun } \\
\text { (helai) }\end{array}$ & $\begin{array}{c}\text { Luas daun } \operatorname{tanaman}^{-1} \\
\left(\mathrm{~cm}^{2}\right)\end{array}$ & $\begin{array}{c}\text { Berat basah bagian atas } \\
\operatorname{tanaman}^{-1}(\mathrm{~g})\end{array}$ \\
\hline $\mathrm{N}_{1} \mathrm{U}_{1}$ & $21.00 \mathrm{~b}$ & $57.72 \mathrm{c}$ & $197.64 \mathrm{~d}$ \\
$\mathrm{~N}_{1} \mathrm{U}_{2}$ & $29.00 \mathrm{a}$ & $70.34 \mathrm{~b}$ & $305.40 \mathrm{~b}$ \\
$\mathrm{~N}_{2} \mathrm{U}_{1}$ & $29.50 \mathrm{a}$ & $59.91 \mathrm{c}$ & $245.52 \mathrm{c}$ \\
$\mathrm{N}_{2} \mathrm{U}_{2}$ & $28.50 \mathrm{a}$ & $74.40 \mathrm{~b}$ & $249.27 \mathrm{c}$ \\
$\mathrm{N}_{3} \mathrm{U}_{1}$ & $29.00 \mathrm{a}$ & $88.25 \mathrm{a}$ & $301.87 \mathrm{~b}$ \\
$\mathrm{~N}_{3} \mathrm{U}_{2}$ & $28.50 \mathrm{a}$ & $87.92 \mathrm{a}$ & $325.69 \mathrm{a}$ \\
\hline Keterangan & $:$ & Nilai yang diikuti oleh huruf yang sama berarti berbeda tidak nyata &
\end{tabular}

\section{Berat Basah Bagian Bawah Tanaman ${ }^{-1}(g)$}

Interaksi dari kedua perlakuan dosis nutrisi $\mathrm{AB}$ mix agrifarm dan umur bibit $(\mathrm{N} \times \mathrm{U})$ menunjukkan pengaruh yang sangat nyata $(\mathrm{P}<0,01)$ pada parameter berat basah bagian bawah tanaman ${ }^{-1}$, sedangkan pengaruh faktor tunggal perlakuan dosis nutrisi $\mathrm{AB}$ mix agrifarm $(\mathrm{N})$ menunjukan pengaruh yang tidak nyata $(p \geq 0,05)$ dan faktor umur bibitmenunjukkan pengaruh yang sangat nyata $(P<0,01)$ (Tabel 1).

Berat basah bagian bawah tanaman ${ }^{-1}$ tertinggi dicapai pada perlakuan $\mathrm{N}_{3} \mathrm{U}_{2}$ yaitu $58.69 \mathrm{~g}$ meningkat sebesar $13.17 \%$ dari hasil yang terendah pada perlakuan $\mathrm{N}_{2} \mathrm{U}_{1}$ yaitu 51.86g (Tabel 4). 


\section{Berat Basah Total $\operatorname{Tanaman}^{-1}(\mathrm{~g})$}

Perlakuan dosis nutrisiAB mix agrifarm $(\mathrm{N})$ dan umur bibit $(\mathrm{U})$ serta interaksi dari kedua perlakuan $(\mathrm{N}$ $\mathrm{x} \mathrm{U})$ menunjukkan pengaruh yang sangat nyata pada parameter berat basah total tanaman ${ }^{-1}$ (Tabel 1).

Rata-rata berat basah total tanaman ${ }^{-1}$ tertinggi dicapai oleh perlakuan $\mathrm{N}_{3} \mathrm{U}_{2}$ yaitu 369,38 gyang berbeda tidak nyataN $\mathrm{U}_{2} \mathrm{U}_{2}$ dengan berat361,26 g (Tabel 4). Hasil berat basah total $\operatorname{tanaman}^{-1}$ terendah didapat pada perlakuan $\mathrm{N}_{1} \mathrm{U}_{1}$ yaitu sebesar $249,89 \mathrm{~g}$.

\section{Berat Basah Ekonomis Tanaman ${ }^{-1}(\mathrm{~g})$}

Perlakuan dosis nutrisiAB mix agrifarm $(\mathrm{N})$ dan umur bibit $(\mathrm{U})$ serta interaksi dari kedua perlakuan $(\mathrm{N}$ x U) menunjukkan pengaruh yang sangat nyata pada parameter berat basah ekonomis tanaman ${ }^{-1}$ (Tabel 1)

Rata-rata berat basah ekonomis tanaman ${ }^{-1}$ tertinggi dicapai oleh perlakuan $\mathrm{N}_{3} \mathrm{U}_{2}$ yaitu 244,69 g meningkat sebesar 57,78\% dari berat basah ekonomis tanaman ${ }^{-1}$ terendah dicapai pada perlakuan $\mathrm{N}_{1} \mathrm{U}_{1}$ yaitu 154,71g (Tabel 4).

Tabel 4. Pengaruh Kombinasi Dosis Nutrisi AB Mix Agrifarm (N) dan Umur Bibit (U) terhadap Berat Basah Bagian Bawah Tanaman $^{-1}$, Berat Basah Total Tanaman ${ }^{-1}$, Berat Basah Ekonomis Tanaman ${ }^{-1}$

\begin{tabular}{|c|c|c|c|}
\hline \multirow[b]{2}{*}{ Perlakuan } & \multicolumn{3}{|c|}{ Parametern } \\
\hline & $\begin{array}{l}\text { Berat Basah } \\
\text { Bagian Bawah } \\
\text { Tanaman }^{-1}(\mathrm{~g})\end{array}$ & $\begin{array}{l}\text { Berat basah total } \\
\text { tanaman }^{-1} \\
(\mathrm{~g})\end{array}$ & $\begin{array}{c}\text { Berat basah ekonomis } \\
\operatorname{tanaman}^{-1} \\
(\mathrm{~g})\end{array}$ \\
\hline $\mathrm{N}_{1} \mathrm{U}_{1}$ & $52.99 \mathrm{c}$ & $249.89 c$ & $154.71 d$ \\
\hline $\mathrm{N}_{1} \mathrm{U}_{2}$ & $56.64 b$ & $282.03 b$ & $183.69 \mathrm{~b}$ \\
\hline $\mathrm{N}_{2} \mathrm{U}_{1}$ & $51.86 c$ & $289.87 b$ & $163.97 \mathrm{c}$ \\
\hline $\mathrm{N}_{2} \mathrm{U}_{2}$ & $58.60 \mathrm{a}$ & $299.62 b$ & $168.91 \mathrm{c}$ \\
\hline $\mathrm{N}_{3} \mathrm{U}_{1}$ & $56.89 b$ & $361.26 a$ & $185.08 \mathrm{~b}$ \\
\hline $\mathrm{N}_{3} \mathrm{U}_{2}$ & $58.69 a$ & $369.38 \mathrm{a}$ & $244.09 \mathrm{a}$ \\
\hline
\end{tabular}

Keterangan : Nilai yang diikuti oleh huruf yang sama berarti berbeda tidak nyata pada uji Duncan's taraf $5 \%$

\section{Berat Basah Non Ekonomis $^{-1}(\mathrm{~g})$}

Perlakuan dosis nutrisiAB mix agrifarm $(\mathrm{N})$ dan umur bibit $(\mathrm{U})$ serta interaksi dari kedua perlakuan (N $\mathrm{x} \mathrm{U})$ menunjukkan pengaruh yang sangat nyata pada parameter berat basah non ekonomis tanaman ${ }^{-1}$ (Tabel 1).

Parameter berat basah non ekonomis tertinggi didapatkan pada perlakuan $\mathrm{N}_{3} \mathrm{U}_{1}$ yaitu 93,01g atau lebih tinggi sebesar $129.99 \%$ dari hasil terendah yang dicapai oleh perlakuan $\mathrm{N}_{1} \mathrm{U}_{1}$ yaitu 40,44g (Tabel 5).

\section{Berat Kering Oven Bagian Atas $\operatorname{Tanaman}^{-1}(\mathrm{~g})$}

Perlakuan dosis nutrisi $\mathrm{AB}$ mix agrifarm(N) dan umur bibit $(\mathrm{U})$ serta interaksi dari kedua perlakuan $(\mathrm{N}$ $\mathrm{x} U$ ) menunjukkan pengaruh yang sangat nyata pada parameter berat kering oven bagian atas $\operatorname{tanaman}^{-1}$ (Tabel 1).

Hasil rata-rata berat kering oven bagian atas tanaman ${ }^{-1}$ hasil tertinggi dicapai oleh perlakuan $\mathrm{N}_{3} \mathrm{U}_{2}$ yaitu 85,90 gmeningkat sebesar $226,49 \%$ dari hasil terendah yang dicapai oleh perlakuan $\mathrm{N}_{1} \mathrm{U}_{1}$ yaitu 26,31g. (Tabel $5)$. 
Tabel 5. Pengaruh kombinasi dosis Nutrisi AB Mix Agrifarm (N) dan umur bibit (U) terhadap Berat basah non ekonomis tanaman ${ }^{-1}$, Berat kering oven(BKO) Bagian atas $\operatorname{tanaman}^{-1}$ dan berat kering oven(BKO)Bagian bawah tanaman ${ }^{-1}$

\begin{tabular}{cccc}
\hline & \multicolumn{3}{c}{ Parameter } \\
\cline { 2 - 4 } Perlakuan & $\begin{array}{c}\text { Berat basah non } \\
\text { ekonomis } \\
\operatorname{tanaman}^{-1}(\mathrm{~g})\end{array}$ & $\begin{array}{c}(\text { BKO) bagian atas } \\
\operatorname{tanaman}^{-1}(\mathrm{~g})\end{array}$ & $\begin{array}{c}(\mathrm{BKO}) \text { bagian bawah } \\
\operatorname{tanaman}^{-1}(\mathrm{~g})\end{array}$ \\
\hline $\mathrm{N}_{1} \mathrm{U}_{1}$ & $40.44 \mathrm{c}$ & $26.31 \mathrm{f}$ & $3.38 \mathrm{c}$ \\
$\mathrm{N}_{1} \mathrm{U}_{2}$ & $81.60 \mathrm{~b}$ & $67.05 \mathrm{~b}$ & $3.90 \mathrm{~b}$ \\
$\mathrm{~N}_{2} \mathrm{U}_{1}$ & $81.55 \mathrm{~b}$ & $35.44 \mathrm{e}$ & $3.58 \mathrm{c}$ \\
$\mathrm{N}_{2} \mathrm{U}_{2}$ & $80.36 \mathrm{~b}$ & $52.74 \mathrm{~d}$ & $4.37 \mathrm{a}$ \\
$\mathrm{N}_{3} \mathrm{U}_{1}$ & $93.01 \mathrm{a}$ & $58.50 \mathrm{c}$ & $3.43 \mathrm{c}$ \\
$\mathrm{N}_{3} \mathrm{U}_{2}$ & $91.60 \mathrm{a}$ & $85.90 \mathrm{a}$ & $4.48 \mathrm{a}$ \\
\hline
\end{tabular}

Keterangan : Nilai yang diikuti oleh huruf yang sama berarti berbeda tidak nyata pada uji Duncan's taraf $5 \%$

\section{Berat Kering Oven Bagian Bawah $\operatorname{Tanaman}^{-1}(\mathrm{~g})$}

Rata-rata berat kering oven bagian bawah tanaman ${ }^{-1}$ tertinggi dicapai oleh perlakuan $\mathrm{N}_{3} \mathrm{U}_{2}$ yaitu $4,48 \mathrm{~g}$ yang berbeda tidak nyata $(\mathrm{P} \geq 0,05)$ dengan perlakuan $\mathrm{N}_{2} \mathrm{U}_{2}$ dengan rata-rata $4,37 \mathrm{~g}$, sedangkan rata-rata terendah didapat berbeda secara nyata $(\mathrm{P}<0,05)$ pada perlakuan $\mathrm{N}_{1} \mathrm{U}_{1}$ yaitu 3,38g (Tabel 5).

\section{Berat Kering Oven Total $\operatorname{Tanaman}^{-1}(\mathrm{~g})$}

Perlakuan dosis nutrisiAB Mix Agrifarm (N) dan umur bibit (U) serta interaksi dari kedua perlakuan (N $\mathrm{x} U$ ) menunjukkan pengaruh yang sangat nyata pada parameter berat kering oven total tanaman ${ }^{-1}$ (Tabel 1).

Beratkering oven total tanaman ${ }^{-1}$ tertinggi didapat pada perlakuan $\mathrm{N}_{3} \mathrm{U}_{2}$ yaitu 90,34g meningkat $205,41 \%$ dari berat terendah yang didapat pada $\mathrm{N}_{1} \mathrm{U}_{1}$ yaitu 29,58g (Tabel 6).

\section{Berat Kering Oven Ekonomis ${ }^{-1}$ (g)}

Perlakuan dosis nutrisi $(\mathrm{N})$ dan umur bibit $(\mathrm{U})$ serta interaksi dari kedua perlakuan $(\mathrm{N} \times \mathrm{U})$ menunjukkan pengaruh yang sangat nyata pada parameter berat kering oven ekonomis $\operatorname{tanaman}^{-1}$ (Tabel 1).

Rata-rata berat kering oven ekonomis tanaman ${ }^{-1}$ tertinggi dicapai oleh perlakuan $\mathrm{N}_{3} \mathrm{U}_{2}$ yaitu $78,10 \mathrm{~g}$ meningkat 293,85\% dari berat terendah yang dicapai oleh perlakuan $\mathrm{N}_{1} \mathrm{U}_{1}$ yaitu 19,83g (Tabel 6).

\section{Berat Kering Oven Non Ekonomis ${ }^{-1}(\mathrm{~g})$}

Berat kering non ekonomis tanaman ${ }^{-1}$ tertinggi dicapai oleh perlakuan $\mathrm{N}_{2} \mathrm{U}_{2}$ yaitu 13,51g yang berbeda tidak nyata dengan perlakuan $\mathrm{N}_{3} \mathrm{U}_{2}$ dengan berat rata-rata yang dicapai seberat $12,97 \mathrm{~g}$, sedangkan berat kering non ekonomis tanaman ${ }^{-1}$ terendah dicapai pada perlakuan $\mathrm{N}_{1} \mathrm{U}_{1}$ yaitu 6,23g (Tabel 6).

Tabel 6. Pengaruh kombinasi dosis Nutrisi AB Mix Agrifarm (N) dan Umur bibit (U) terhadap Berat kering oven(BKO) totaltanaman ${ }^{-1}$, Berat kering oven(BKO)ekonomis tanaman ${ }^{-1}$, BKO non ekonomis tanaman $^{-1}$ dan Indek Panen.

\begin{tabular}{ccccc}
\hline & \multicolumn{4}{c}{ Parameter } \\
\cline { 2 - 5 } Perlakuan & $\begin{array}{c}(\mathrm{BKO}) \\
\text { totaltanaman }^{-1}\end{array}$ & $\begin{array}{c}(\mathrm{BKO}) \text { ekonomis }^{-1} \\
\operatorname{tanaman}^{-1}(\mathrm{~g})\end{array}$ & $\begin{array}{c}\text { BKO non } \\
\text { ekonomis } \\
\operatorname{tanaman}^{-1}(\mathrm{~g})\end{array}$ & $\begin{array}{c}\text { Indek Panen } \\
(\%)\end{array}$ \\
\hline $\mathrm{N}_{1} \mathrm{U}_{1}$ & $29.58 \mathrm{f}$ & $19.83 \mathrm{f}$ & $6.23 \mathrm{e}$ & $67.34 \mathrm{~d}$ \\
$\mathrm{~N}_{1} \mathrm{U}_{2}$ & $70.92 \mathrm{~b}$ & $37.98 \mathrm{~d}$ & $7.88 \mathrm{~d}$ & $82.19 \mathrm{~b}$ \\
$\mathrm{~N}_{2} \mathrm{U}_{1}$ & $39.02 \mathrm{e}$ & $31.88 \mathrm{e}$ & $11.31 \mathrm{~b}$ & $82.19 \mathrm{~b}$ \\
$\mathrm{~N}_{2} \mathrm{U}_{2}$ & $58.83 \mathrm{~d}$ & $59.09 \mathrm{~b}$ & $13.51 \mathrm{a}$ & $100.75 \mathrm{a}$ \\
$\mathrm{N}_{3} \mathrm{U}_{1}$ & $61.94 \mathrm{c}$ & $45.56 \mathrm{c}$ & $10.19 \mathrm{c}$ & $73.65 \mathrm{c}$ \\
$\mathrm{N}_{3} \mathrm{U}_{2}$ & $90.34 \mathrm{a}$ & $78.10 \mathrm{a}$ & $12.97 \mathrm{a}$ & $86.24 \mathrm{~b}$ \\
\hline
\end{tabular}

Keterangan : Nilai yang diikuti oleh huruf yang sama berarti berbeda tidak nyata pada uji Duncan's taraf $5 \%$ 


\section{Indeks Panen (\%)}

Perlakuan dosis nutrisi $(\mathrm{N})$ dan umur bibit $(\mathrm{U})$ serta interaksi dari kedua perlakuan $(\mathrm{N} \times \mathrm{U})$ menunjukkan pengaruh yang sangat nyata pada parameter indeks panen\% $\operatorname{tanaman}^{-1}$ (Tabel 1).

Pada indeks panen tertinggi dicapai oleh perlakuan $\mathrm{N}_{2} \mathrm{U}_{2}$ yaitu $100,75 \%$ meningkat sebesar $188,14 \%$ dari berat terendah yang dicapai oleh $\mathrm{N}_{1} \mathrm{U}_{2}$ yaitu $53,55 \%$ (Tabel 6).

\section{Pembahasan}

Berat Kering Oven (BKO) hasil ekonomis tanaman ${ }^{-1}$ tertinggi dihasilkan oleh perlakuan kombinasi $\mathrm{N}_{3} \mathrm{U}_{2}$ yaitu sebesar 78,10 g. Tingginya BKO hasil ekonomis tanaman ${ }^{-1}$ didukung oleh parameter yang lain seperti berat basah total tanaman ${ }^{-1}$, berat basah ekonomis tanaman ${ }^{-1}$, jumlah daun dan luas daun tanaman ${ }^{1}$ yang selalu menunjukkan hasil pada perlakuan kombinasi dosis nutrisi $\mathrm{AB}$ mix agrifarm $1250 \mathrm{ppm}$ dengan umur bibit 2 minggu $\left(\mathrm{N}_{3} \mathrm{U}_{2}\right)$. Nilai rata-rata berat basah total tanaman ${ }^{-1}$, berat basah ekonomis tanaman ${ }^{-1}$ pada perlakuan $\left(\mathrm{N}_{3} \mathrm{U}_{2}\right)$ masing-masing secara berurutan sebesar 369,38 $\mathrm{g}$ dan 244,09 $\mathrm{g}$.

Hasil BKO hasil ekonomis tanaman ${ }^{-1}$ tertinggi pada perlakuan kombinasi $\mathrm{N}_{3} \mathrm{U}_{2}$ adalah meningkat $293,85 \%$ dibandingkan dengan nilai terendah yang didapat pada perlakuan $\mathrm{N}_{1} \mathrm{U}_{1}$. Peningkatan hasil ini berkaitan erat dengan pemenuhan unsur-unsur hara yang dibutuhkan oleh tanaman pakcoy dengan dosis nutrisi $\mathrm{AB}$ mix agrifarm $1250 \mathrm{ppm}$ pada umur bibit 2 minggu sudah terpenuhi, sehingga mendapatkan pertumbuhan dan hasil tanaman yang optimal. Tingginya peningkatan hasil BKO tanaman ${ }^{-1}$ juga tidak lepas dari peranan yang sangat penting dari suatu unsur hara yang terkandung pada larutan nutrisi yang diberikan pada tanaman.Di dalam pemberian nutrisi pada tanaman harus seimbang baik unsur hara makro dan unsurhara mikro karena ketidak seimbangan itu dapat menyebabkan pertumbuhan dan perkembangan tanaman menjadi terhambat. Nutrisi memegang peranan penting bagi pertumbuhan tanaman pakcoy karena berfungsi sebagai penyuplai makanan utama bagi tanaman pakcoy itu sendiri. Oleh karena itu pemberian nutrisi akan menentukan baik atau tidaknya pertumbuhan tanaman pakcoy, pemberian nutrisi dalam jumlah dan dosis yang tepat akan meningkatkan pertumbuhan tanaman pakcoy, hal ini sesuai dengan pendapat Lestari (2009), bahwa nutrisi yang diberikan pada tanaman harus dalam komposisi yang tepat.

Berat basah ekonomis tanaman ${ }^{-1}$ juga dipengaruhi oleh jumlah daun tanaman ${ }^{-1}$. Hasil ini sesuai dengan pernyataan Polii (2009), dalam penelitiannya yang mengemukakan meningkatnya jumlah daun tanaman akan meningkatkan berat segar tanaman, karena daun merupakan sink bagi tanaman sayuran. Dengan jumlah daun yang banyak, luas daun tanaman ${ }^{-1}$ juga semakin tinggi, maka kadar air dalam tanaman akan tinggi dan menyebabkan berat segar tanaman semakin tinggi pula. Peningkatan luas daun akan menyebabkan bahan kering (dry metter) atau asimilat yang dihasilkan dari proses fotosintesis, akan lebih banyak digunakan dalam pembentukan bagian hasil ekonomis tanaman, di mana luas daun tertinggi dihasilkan oleh perlakuan kombinasi $\mathrm{N}_{3} \mathrm{U}_{1}$ yaitu $88,25 \mathrm{~cm}^{2}$ yang berbeda tidak nyata dengan perlakuan $\mathrm{N}_{3} \mathrm{U}_{2}$ yaitu sebesar $87,92 \mathrm{~cm}^{2}$ meningkat $52,89 \%$ dari hasil terendah perlakuan kombinasi $\mathrm{N}_{1} \mathrm{U}_{1}$ yaitu $57,72 \mathrm{~cm}^{2}$.

Meningkatnya luas daun disebabkan oleh meningkatnya jumlah daun tanaman ${ }^{-1}$, sehingga proses fotosintesis juga meningkat. Menurut Garner et al. (1985) menyatakan bahwa tingginya indeks luas daun sampai batas tertentu menyebabkan tingginya intersepsi cahaya mata hari per satuan luas, tingginya aktivitas fotosintesis tanaman dan diikuti lebih besarnya akumulasi fotosintat. Lebih lanjut Abidin, (1984) menyatakan bahwa luas daun sangat berperan dalam proses intersepsi cahaya matahari dalam peristiwa fotosintesis.

Tinggi tanaman dan jumlah daun tanaman sangat dipengaruhi oleh pemberian nutrisi yang cukup mengandung unsur hara makro dan mikro secara seimbang, selain nutrisi tinggi tanaman dipengaruhi oleh faktor genetiknya seperti yang dijelaskan oleh Lingga (2003), bahwa tinggi tanaman dipengaruhi oleh faktor genetik dan kondisi lingkungan tempat tumbuh tanaman. Jika pemberian perlakuan nutrisi yang mengandung unsur N,P dan K yang tersedia tidak dalam jumlah yang cukup dan seimbang bagi tanaman pakcoy sehingga pemberian nutrsi tidak meningkatkan pertumbuhan tanaman. Syafrudi, dkk.(2012) menyatakan bahwa untuk dapat tumbuh dengan baik tanaman membutuhkan hara $\mathrm{N}, \mathrm{P}$ dan $\mathrm{K}$ yang merupakan unsur hara esensial dimana unsur hara ini sangat berperan dalam pertumbuhan tanaman secara umum pada fase vegetatif.

Peningkatan fotosintesis akan menghasilkan fotosintat semakin banyak sehingga berat kering bagian atas tanaman akan meningkat, fotosintat dan energi yang dihasilkan digunakan untuk membentuk dan menjaga kualitas daun. Meningkatnya berat kering bagian atas $\operatorname{tanaman}^{-1}$ di atas tanah menjelaskan pertumbuhan yang terjadi pada bagian vegetatif pakcoy yang menunjukkan adanya akumulasi bahan organik 
yang dihasilkan dari proses fotosintesis. Prawiranata et al. (1981), menyatakan bahwa peningkatan berat kering tanaman menunjukkan pertumbuhan vegetatif berjalan dengan baik. Menurut Perwitasari (2012), bobot kering hasil panen suatu tanaman budidaya merupakan peningkatan asimilasi $\mathrm{CO}_{2}$ bersih selama pertumbuhan vegetatif tanaman pakcoy. Diduga hal ini disebabkan oleh kandungan unsur hara kalium yang terdapat pada nutrisi.

\section{SIMPULAN DAN SARAN}

\section{Simpulan}

Berdasarkan hasil penelitian di atas dapat disimpulkan beberapa hal sebagai berikut :

1. Interaksi antara perlakuan dosis nutrisi $\mathrm{AB}$ mix Agrifarm dan umur bibit $(\mathrm{N} x \mathrm{U})$ berpengaruh sangat nyata $(\mathrm{p}<0,01)$ terhadap seluruh parameter yang diamati, kecuali pada tinggi tanaman umur 35 hst yang berpengaruh tidak nyata $(\mathrm{p} \geq 0,05)$.

2. Berat basah ekonomis tanaman ${ }^{-1}$ dan BKO hasil ekonomis tanaman ${ }^{-1}$ tertinggi dihasilkan pada perlakuan kombinasi $\mathrm{N}_{3} \mathrm{U}_{2}$ yaitu sebesar masing-masing secara berurutan $244,09 \mathrm{~g}$ dan $78.10 \mathrm{~g}$ atau meningkatasingmasing 57,78\% dan 293,85\% dibandingkan dari hasil terendah yang dihasilkan oleh perlakuan kombinasi $\mathrm{N}_{1} \mathrm{U}_{1}$ yaitu sebesar $154,71 \mathrm{~g}$ dan $19,83 \mathrm{~g}$

\section{Saran-saran}

Berdasarkan simpulan di atas maka dapat disarankan beberapa hal antara lain :

1. Budidaya hidroponik sayuran pakcoy yang dilakukan disarankan menanam dengan umur bibit 2 minggu dan menggunakan dosis nutrisi $\mathrm{AB}$ mix Agrifarm pada dosis $1250 \mathrm{ppm}$ untuk mendapatkan hasil yang maksimal.

2. Perlu dilakukan penelitian hidroponik menggunakan nutrisi $\mathrm{AB}$ mix agrifarm yang diaplikasikan pada berbagai jenis tanaman, sehingga mendapat informasi yang lebih banyak tentang penggunaan dosis nutrisi $\mathrm{AB}$ mix agrifarm.

\section{DAFTAR PUSTAKA}

Abidin.1984. Anatomi Tumbuhan. PT. Penebar Swadaya. Lembang

Gardner, F. P Pearce, RB., Mitchel, R.L.1985. Fisiologi Tanaman Budidaya: Universitas Indonesia (Terjemahan). Jakarta

Gardner FB, Pearce RB, and Mitchell RL. 1991. Phsycology of crop Anatomi. Diterjemahkan oleh H.

Susilo. UniversitasIndonesia Pers. Jakarta

Haryanto,2001. Sawi dan Selada.Edisi revisi. Penebar Swadaya, Jakarta. Hal 170.

Lestari, T. 2009. Dampak Konversi Lahan Pertanian Bagi Taraf Hidup Petani. Skripsi. $\quad$ Bogor.Institut Pertanian Bogor.

Lingga.P, 2003. Petunjuk Penggunaan Pupuk. Penebar Swadaya. Jakarta. 2006. Hidroponik Bercocok Tanam Tanpa Tanah. Penebar Swadaya. Jakarta

Lingga.P dan Marsono,2005. Petunjuk Penggunaan Pupuk. Penebar Swadaya, Jakarta.50 hal.

Perwitasari,B., Mustika T., Catur . W. 2012. Pengaruh Media Tanaman dan Nutrisi Terhadap Pertumbuhan dan Hasil Tanaman Pakcoy (Brassicachinensis) Dengan Sistem Hidroponik .Agrovigor :5 (1) : 14- 25.

Prawiranata,W., S.Harran dan P. Tjonndro Negoro. 1981. Dasar - dasar Fisiologi Tumbuhan. Jilid II. Dept. Botani Fakultas Pertanian IPB Bogor.Hal 41.

Syafruddin, Nurhayati, dan Wati, R. 2012. Pengaruh Jenis Pupuk Terhadap Pertumbuhan dan Hasil Beberapa Varietas Jagung Manis. Jurnal Fakultas Pertanian Universitas Syiah Kuala Darussalam Banda-Aceh.Hal 107-104.

Suhardiyanto, H. 2006. Teknologi Hidroponik Untuk Budidaya Tanaman.Institut Pertanian Bogor Press Bogor.

Susila, 2009.Istilah Hidroponik.Penebar Swadaya, Jakarta.

Vavrina, CS. 1998.Transplant age in vegetable crops HortTechnology.8:1-7 